\title{
Gamma-sarcoglycanopathy (LGMD 2C) with Del 525T mutation: report of the first familial case in Niger
}

\author{
H. MOUMOUNI ${ }^{1 *}$, H. ASSADECK ${ }^{1}$, S. GUIDA ${ }^{1}$, B. S. SOUNA ${ }^{1}$, R. ADAL ${ }^{1}$, \\ J. A. URTIZBEREA ${ }^{2}$, F. LETURCQ ${ }^{2}$ and R. B. DARBOUX ${ }^{3}$ \\ ${ }^{I}$ Faculté des Sciences de la Santé de Niamey, Laboratoire d'Histo-Embryologie, Neurologie, Radiologie \\ Traumato-Orthopédie, Niger. \\ ${ }^{2}$ Hôpital Marin de Handaye, France. \\ ${ }^{3}$ Faculté des Sciences de la Santé de Cotonou, Laboratoire de Biologie Humaine, Benin. \\ "Corresponding author, E-mail: mohassa_ne@yahoo.com; BP10896 Niamey, Niger.
}

\begin{abstract}
We are reporting a familial case of limb-girdle muscular dystrophy (LGMD) upon 5 out of 6 siblings from parents showing no evidence of muscular dystrophy. The pedigree of the family up to five generations did not reveal any known case in the past even though consanguinity was reported. The clinical observations revealed wheelchair bound or difficulties for walking in all affected subjects, due to muscular dystrophy involving mainly the pelvic girdle. Creatine phosphoKinase (CK) was higher than normal values in both affected children and their parents. The scanning of thigh showed in all patients, an atrophy of the quadriceps with fatty conversion. Molecular analysis was carried out, first using western blot, which revealed gammasacoglycan deficiency and second, by gene screening, which showed Del 525T mutation. This mutation is most widespread in arabo-berbères tribes including Touaregs. The present cases are in our knowledge the first reported in that part of Africa, south of Maghreb. We make a focus on histological and molecular bases of the LGMD.

(C) 2011 International Formulae Group. All rights reserved.
\end{abstract}

Keywords: gamma-sarcoglycanopathy, LGMD 2C, Del 525T mutation, Niger .

\section{INTRODUCTION}

The myopathy referred mainly to Duchenne muscular dystrophy that was described by Duchenne in the middle of the $19^{\text {th }}$ century. This anomaly, recessive X-linked transmitted, affects exclusively men. Nowadays, many types of muscular diseases are known, based on their clinical and histopathological aspects, and the molecular bases of most of them are_elucidated (Weiler and al., 1999; Leturcq and Kaplan, 2000;
Urtizberea, 2001; Authier et al., 2008). A particular interest in investigating these pathologies was raised in developed countries around 1980 following the era of advances in molecular genetics (Gilchrist and al., 1988; Beckmann et al., 1991; Ginjaar et al., 2000; Sandona and Betto, 2009). It has been shown that these pathologies derive from anomalies in proteins involved in muscle cell structures or functions. The contractibility of muscle cells is enabled by the presence of filaments 
like actin, myosin, tropomyosin, and intermediate filaments, desmin particularly. They contain myoglobin, a pigment which fixes oxygen. Many other proteins are present in the cell plasma under the sarcolemma: integrins, spectrin, and the complex Dystrophine / Dystrophine Associated Glycoproteins (DAGs). The complex Dystrophine/DAGs is particularly involved in the occurrence of myopathies. The DAGs contain about 15 proteins which are linked to dystrophine. These proteins can be divided into 4 subgroups: dystroglycans, sarcoglycans, syntrophines and dystrobrevine. Although their functions are only partially known, it is clear that the complex dystrophine/DAGs participates in the stability of the sarcolemma. Moreover, deficiency in one element of this complex has been shown to alter all the system, then leading to fibber necrosis and fibrosis (Fanin et al., 1997; Leturcq and Kaplan, 2000; Authier et al., 2008; Sandona, and Betto, 2009). The diversity of the proteins that are involved in this phenomenon explains the numerous types of myopathies. The majority of myopathies are genetically transmitted, in variable ways: autosomic, Xlinked, recessive, dominant (Eymard et al., 1997; Gilchrist et al., 1988; Bonne et al., 1999; Speer et al., 1999). In spite important similarities, differences also exist in their clinical expression. Nevertheless, several probes exist now and are of great interests in molecular identification of the myopathies (Nigro et al., 1996; Leturcq and Kaplan, 2000; Khadilkar et al., 2009; Sandona and Betto, 2009).

In African countries such as Niger, muscular diseases are poorly known and are considered as a punishment from the nature. Here we report 5 cases of gamma sarcoglycanopathy in a consanguineous family of 6 siblings with clinical, histopathological and molecular confirmation. The objectives of the work were to enhance the knowledge of these muscular diseases as regards both clinical expression and molecular supports.

\section{MATERIALS AND METHODS}

The study population is a touareg family from Agadez (North of Niger), living in Niamey. Five of the 6 siblings were affected by a severe muscular dystrophy. The father and the mother were linked by a consanguineous marriage. They were respectively 47 and 38 years old and showed no clinical symptoms. The siblings included 3 females (with a twin pair) and 3 males with ages ranging from 8 through 18 years (Figure 1). We performed a full neurological examination followed by a general examination for the whole family. Then we used all clinical and laboratory investigation data after 10 years follow up. Laboratory investigations included cardiac ultrasonography, electrocardiogram, CT scan of the thigh and creatine phosphokinase (CK). A muscular biopsy was performed for western-blot using specific antibodies against dystrophine, dysferlin, calpain and sarcoglycans. The western blot test was followed by direct gene sequencings. During the study, regular home visits were organized to be in touch with the family and provide counselling and helps.

\section{RESULTS}

The pedigree allowed consanguinity rate evaluation (coefficient 0.0625 ). Only the hypothesis of autosomic recessive transmission can be accepted for this disease. The heterozygote of the subject V.6 has been added after the results of molecular biology test.

Data provided by Bio-clinical investigations showed for all affected children an onset age around 9-10 years, an evidence of pelvic deficiency at age of 11 and wheelchair bounds at 13 . CK were high in all family members, even in the heterozygotes. Cardio-respiratory and intelligence evaluations were normal. CT scan of thigh in 
affected subjects revealed atrophy of quadriceps with fatty conversion (Figure 2). The details of the main tests that were performed are summarized in Table 1.

Deficits in calpain and dysferlin have been tested by Western-blot and gene sequencings they are also responsible for limb-girdle muscular dystrophies transmitted in autosomic recessive way.
According to the touareg origin of the family, the delta 525T mutation that was known in arabo-berbères was first researched and confirmed in all the family members. Subjects V.1, 2, V.3, V.4 and V.5 were studied while the 2 parents and V.6 were heterozygote.

The Western blot test revealed a deficiency in gamma-sarcoglycan (Figure 3).

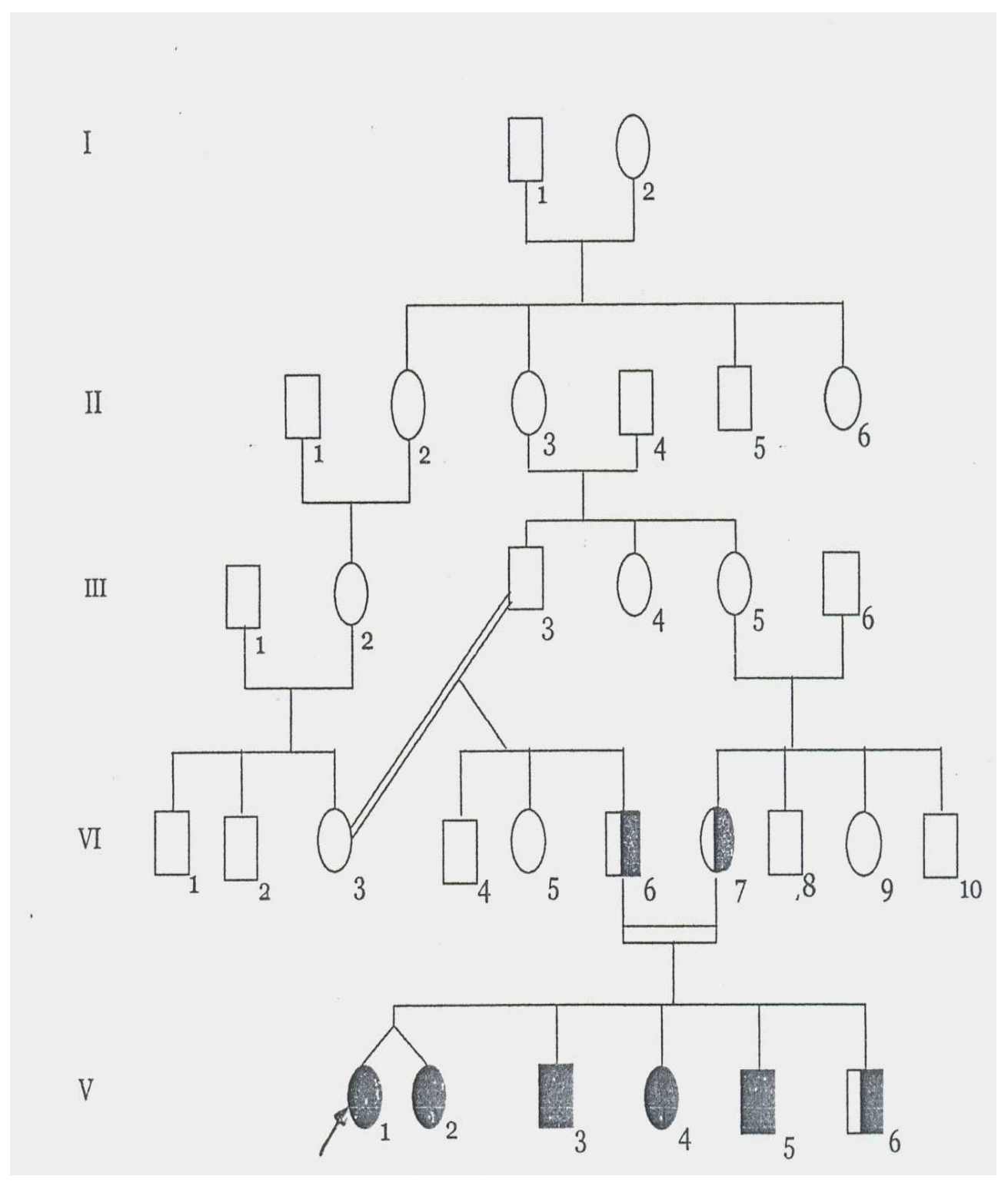

Figure 1: Family's pedigree on five generations. 


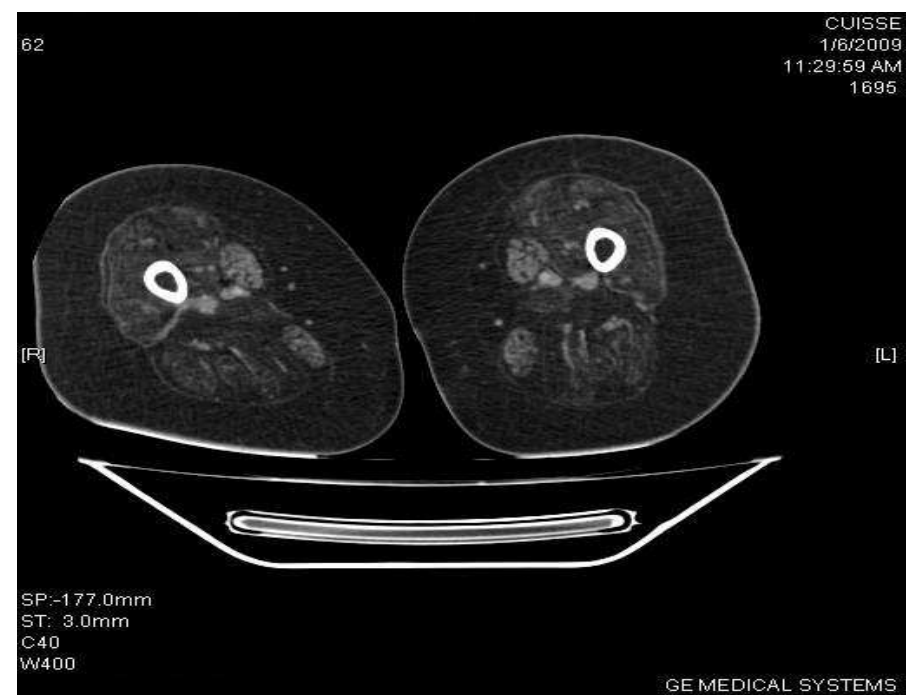

Subject V.3, 17 years old, wheelchair bound since 4 years. Note the muscular atrophy with fatty reconversion.

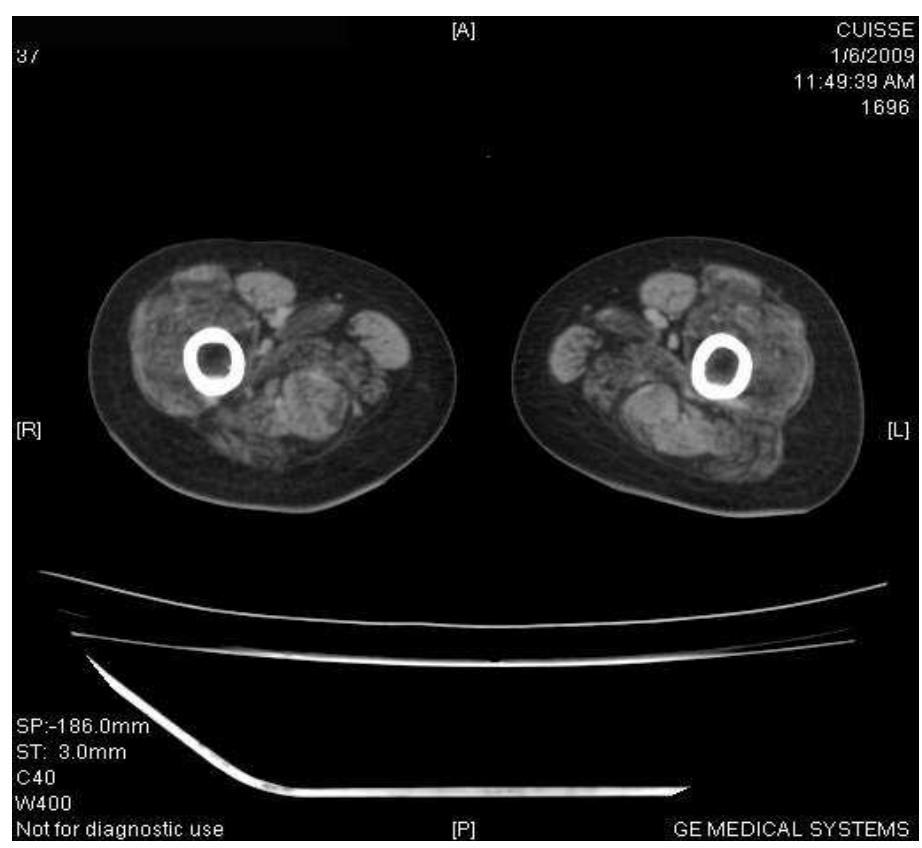

Subject V.5, 11 years old, showing pelvic deficit, still walking, but with difficulty. Note the importance of atrophy and fatty reconversion. 


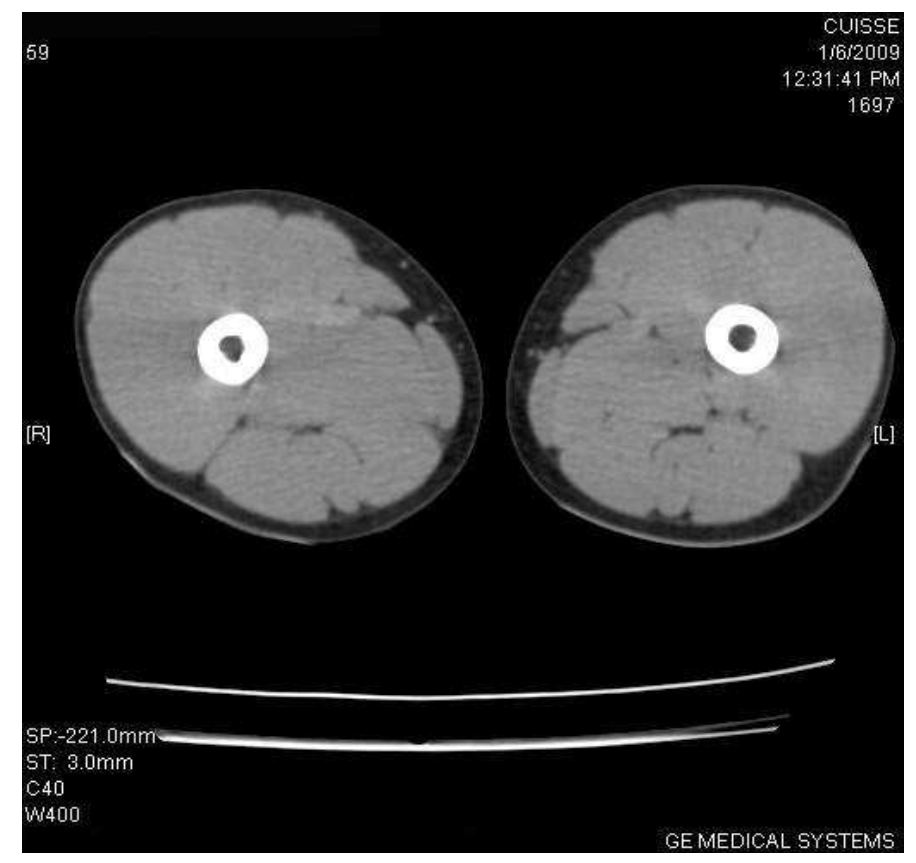

Subject V.6, 8 years old, heterozygote, walks normally. Images are in normal limits.

Figure 2: CT Scan of the thigh of 2 affected subjects (V.3 and V.5) and of 1 heterozygote.

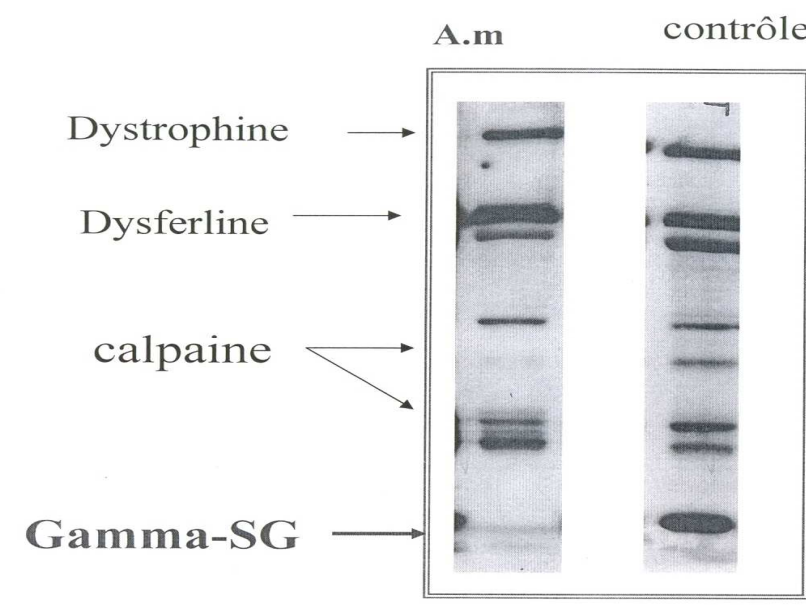

Western-blot Multiplex

Figure 3: Evidence of gamma-sarcoglycan deficiency by western-blot test in subject V.3. 
H. MOUMOUNI et al. / Int. J. Biol. Chem. Sci. 5(6): 2185-2194, 2011

Table 1: Summary of the main bio clinical observations in the study subjects.

\begin{tabular}{|c|c|c|c|c|c|c|c|c|}
\hline & $\begin{array}{c}\text { IV.6 } \\
\text { (father) }\end{array}$ & $\begin{array}{c}\text { IV.7 } \\
\text { (mother) }\end{array}$ & $\begin{array}{c}\text { V.1, 2* } \\
\text { (daughters) }\end{array}$ & $\begin{array}{c}\mathbf{V . 3} \\
\text { (son) }\end{array}$ & $\begin{array}{c}\mathbf{V . 4} \\
\text { (daughter) }\end{array}$ & $\begin{array}{c}\mathbf{V . 5} \\
\text { (son) }\end{array}$ & $\begin{array}{c}\mathbf{V . 6} \\
\text { (son) }\end{array}$ & Observations \\
\hline $\begin{array}{l}\text { walking difficulties } \\
\text { onset }\end{array}$ & None, & None, & 9 years & 11 years & 11 years & $\begin{array}{l}11 \text { years } \\
\text { (real age) }\end{array}$ & $\begin{array}{c}\text { None, } 8 \text { years } \\
\text { really }\end{array}$ & beginning 9-11ans \\
\hline Pelvic deficiciency & None, & $\begin{array}{c}\text { None, } \\
\text { knees pain }\end{array}$ & 11 years & 11 years & 11 years & 11 years & None & 11 years in all cases \\
\hline Wheelchair bound & No & No & 13 years & 13 years & 13 years & $\mathrm{No}^{* *}$ & No & $\begin{array}{c}13 \text { years for the } 4 \text { first } \\
\text { affected }\end{array}$ \\
\hline $\begin{array}{l}\text { Cardio-respiratory } \\
\text { examination }\end{array}$ & Normal & Asthma & palpitations & palpitations & Normal & Normal & Normal & Poor anomalies \\
\hline $\begin{array}{l}\text { CK }(\mathbf{U I} / \mathbf{L}) \\
\text { (Normal value: 0- } \\
\text { 195UI/L) }\end{array}$ & 257 & 833 & $622-789$ & 2317 & 1849 & $\begin{array}{c}13790 \text { (at } 5 \\
\text { years) } \\
4810(\text { real }) \\
\end{array}$ & $\begin{array}{c}270 \text { (at } 2 \text { years) } \\
499 \text { (real) }\end{array}$ & $\begin{array}{c}\text { High in all cases } \\
\text { But always }<1000 \text { in } \\
\text { heterozygotes }\end{array}$ \\
\hline Thigh CT Scan & - & - & - & $\begin{array}{l}\text { Atrophy of } \\
\text { quadriceps } \\
\text { and posterior } \\
\text { muscles of the } \\
\text { thigh }\end{array}$ & - & $\begin{array}{c}\text { Atrophy of } \\
\text { quadriceps and } \\
\text { posterior } \\
\text { muscles of the } \\
\text { thigh }\end{array}$ & Normal & $\begin{array}{c}\text { Atrophy of quadriceps } \\
\text { constant }\end{array}$ \\
\hline Molecular biology & $\begin{array}{l}\text { Heterozygote } \\
\text { Delta 525T }\end{array}$ & $\begin{array}{c}\text { Heterozygote } \\
\text { Delta } 525 \mathrm{~T}\end{array}$ & - & $\begin{array}{l}\text { Homozygote } \\
\text { Delta 525T }\end{array}$ & - & $\begin{array}{l}\text { Homozygote } \\
\text { Delta 525T }\end{array}$ & $\begin{array}{c}\text { Heterozygote } \\
\text { Delta 525T }\end{array}$ & $\begin{array}{l}\text { ** will probably loss } \\
\text { walking capacity while } \\
\text { V.6 will be surely free of } \\
\text { the disease }\end{array}$ \\
\hline
\end{tabular}


H. MOUMOUNI et al. / Int. J. Biol. Chem. Sci. 5(6): 2185-2194, 2011

Table 2: Summarises some new proteins and genes involved in limb-girdle myopathies.

\begin{tabular}{cccccc}
\hline $\begin{array}{c}\text { Classification } \\
\text { Type* }\end{array}$ & Protein & gene & $\begin{array}{c}\text { Classification } \\
\text { Type* }\end{array}$ & Protein & gene \\
\hline 1A & Myotilin & $5 \mathrm{q} 22$ & $2 \mathrm{~A}$ & Calpain & $15 \mathrm{q} 15$ \\
1B & Lamin A/C & $1 \mathrm{q} 11$ & $2 \mathrm{~B}$ & Dysferlin & $2 \mathrm{p} 13$ \\
1C & Caveolin & $3 \mathrm{p} 25$ & $2 \mathrm{C}$ & $\gamma$-sarcoglycan & $13 \mathrm{q} 12$ \\
1D & $?$ & $6 \mathrm{q} 23$ & $2 \mathrm{D}$ & $\alpha$-sarcoglycan & $17 \mathrm{q} 12$ \\
1E & $?$ & $7 \mathrm{q}$ & $2 \mathrm{E}$ & $\beta$-sarcoglycan & $4 \mathrm{q} 12$ \\
\hline
\end{tabular}




\section{DISCUSSION}

The pedigree analysis shows in spite of its singularity to assume autosomic recessive transmission, giving orientation towards the subgroup of myopathies to be tested. Pedigree analysis is not easy for genetic counselling even if we consider that the twins were monozygotes, the chance to observe 5 affected subjects in an offspring of 6 is less than $1 / 60$ 000 for an expected risk of $1 / 4$. This pedigree gives support of targets for a wide research in the extended family by using these molecular probes. By matching these data and those provided by molecular analysis we confirmed to the parents that their last son (V.6) will not develop the full disease and we notify to them their ability to have unaffected offspring. The touareg origins of the family help us focus first on the Delta 525T mutation, which has been confirmed by gene screening (Ben Hamida et al., 1983; Fanin et al., 1997; Moreira et al., 1998; Leturcq and Kaplan, 2000). Regarding the high rate of consanguinity found in the present study, further research should be extended to the large family. This will help in detecting heterozygotes and in preventing high-risk unions. The Delta 525T mutation was listed first as Delta 521T and is the most frequent cause of sarcoglycanopathy in patients of Maghreb origins. In Maghreb countries, it represents up to $50 \%$ of progressive muscular dystrophies in children versus 10 to $15 \%$ in Europe or United States. Our cases were the first to be reported in this part of Africa, in the south of Maghreb. Origins of Delta 525T mutation are yet discussed, but the high frequency in Maghreb allows the hypothesis of an existing link with arabo-berbers. The observation of cases in Mediterranean region (Libya, Jordan, Libanon, Saudi Arabia, Tunisia, etc.) and now in Niger can be explained by migration flows in this area (BenHamida et al., 1983; Urtasun et al., 1998; Ginjaar et al., 2000; Merlini et al, 2000; Khadilkar et al, 2009). The line between Touaregs and arabo-berbers is now well established; then it is not surprising to observe the Delta 525T mutation in this ethnic group.
Paraclinic examinations revealed a rise of creatine phosphokinase (CK) in all members of the family but levels were $<1000$ $\mathrm{U} / \mathrm{L}$ in heterozygotes. In addition, a muscular atrophy with fatty reconversion was clear in all homozygotes since the age of 8 .

Sarcoglycanopathies belong to the Limb Girdle Muscular dystrophies (LGMD) $2 \mathrm{D}, 2 \mathrm{E}, 2 \mathrm{~F}$, and $2 \mathrm{C}$ in the nomenclature of European Neuromuscular Centre (ENMC) (Nigro et al., 1996; Sandona and Betto, 2009; Urtizberea, 2001). Their clinical expression is so similar that sometimes only immunochemistry or mutation analysis can help distinguishing them. Myocardiopathy is usually rare in sarcoglycanopathies.

Gamma-sarcoglycanopathy (LGMD 2C) results from a molecular deficit in gamma-sarcoglycan, a protein of $25 \mathrm{kD}$, encoded by a gene located on $13 \mathrm{q}_{12}$. Although cases have been reported in numerous countries, 2 ethnic groups are mainly involved: arabo-berbers and gipsy, which are known with important consanguineous marriage. In arabo-berbers the mutation is Delta 525T and C283Y in gipsy. Seven other mutations were reported, involving the same gene (Fanin et al., 1997; Urtasun et al., 1998; Merlini et al., 2000).

Myopathies resulting from anomalies of other proteins have been reported: (calpain, telethonin, dysferlin, myotilin, lamin, caveolin, etc.) (Liu et al., 1998; Mc Nally et al., 1990; Baghdiguian et al., 1999; Bonne et al., 1999; Hauser et al., 2000). Other myopathies rise from more complex disturbances e.g. a repetition of triplets (Steinert myopathy) or as the consequence of abnormal unknown proteins as reported by Speer et al. (1999) in Landouzy-Déjerine, LGMD 1D, LGMD 1E, etc. (Table 2).

\section{REFERENCES}

Authier FJ, Bassez G, Prost-Squarcioni C, Copin H. 2008. Les tissus musculaires. In Histologie: Bases Fondamentales. OMNISCIENCE : Paris ; 141-189.

Baghdiguian S, Martin M, Pons F, Richard I, Astier C, Bourg N, Hay RT, Chemaly R, 
Halaby G, Loiselet J, Anderson LVB, Lopez de Munain A, Fardeau M, Mangeat P, Beckmann JS, Lefranc G. 1999. Calpain 3 deficiency is associated with muscular apoptosis and profound perturbation of pathway in limb-girdle muscular dystrophy type 2A. Nature Medicine, 5: 503-511.

Beckmann JS, Richard I, Hillaire D, Broux O, Antignac C, Bois E, Cann H, Cottingham RWJr, Feingold N, Feingold J. 1991. A gene for limb-girdle muscular dystrophy maps to the chromosome 15 by linkage. CR Acad Sci Paris, 312: 141148.

Ben Hamida M, Fardeau M, Attia N. 1983. Severe childhood muscular dystrophy affecting both sexes and frequent in Tunisia. Muscle and Nerve, 6: 469-480.

Bonne GB, Di Barletta Mr, Varnous S, Bécane HM, Hammouda EH, Merlini L, Muntoni F, Greenberg CR, Gary F, Urtizberea JA, Duboc D, Fardeau M, Toniolo D, Schwartz K. 1999. Mutations in the gene encoding lamin A/C causes autosomal dominant EmeryDreifuss muscular dystrophy. Nature Genet, 21: 285-88.

Eymard B, Romero NB, Leturcq F, Piccolo F, Carrié A, Jean-Pierre M, Collin H, Deburgrave N, Azibi K, Chaouch M, Merlini L, Thémar-Noël C, Penisson I, Mayer M, Tanguy O, Campbell KP, Kaplan JC, Tomé FM, Fardeau M. 1997. Primary adhalinopathy (alphasarcoglycanopathy): clinical, pathologic and genetic correlation in 20 patients with autosomal recessive muscular dystrophy. Neurol, 48(5): 1227-1234.

Fanin M, Duggan DJ, Mostacciuolo Ml, Martinello F, Freda MP, Sorarù G, Trevisan CP, Hoffman EP, Angelini C. 1997. Genetic epidemiology of muscular dystrophies resulting from sarcoglycan gene mutations. J. Med. Genet., 34: 97377.

Gilchrist J, Pericak-Vance M, Silverman L, Roses A. 1988. Clinical and genetic investigation in autosomal dominant limb-girdle muscular dystrophy. Neurol, 38: $5-9$.

Ginjaar HB, Van Der Kooi AJ, Ceelie H, Kneppers AL, Van Meegen M, Barth PG, Busch HF, Wokke JH, Anderson LV, Bönnemann CG, Jean-Pierre M, Bolhuis PA, Moorman AF, De Visser M, Bakker E, Ommen GJ. 2000. Sarcoglycanopathies in Dutch patients with autosomal recessive limb girdle muscular dystrophy. Neurol, 247(7): 524529.

Hauser MA, Horrigan SK, Salmikangas P, Torian UM, Viles KD, Dancel R, Tim RW, Taivainen A, Bartoloni L, Gilchrist JM, Stajich JM, Gaskell PC, Gilbert JR, Vance JM, Pericak-Vance MA, Carpen O, Westbrook CA, Speer MC. 2000. Myotilin is mutated in limb girdle muscular dystrophy 1A. Hum. Mol. Genet., 9(14): 2141-2147.

Khadilkar SV, Singh RK, Hegde M, Urtizberea JA, Love DR, Chong B. 2009. Spectrum of mutations in Sarcoglyn genes in the Mimbai region of western India: high prevalence of $525 \mathrm{del} \mathrm{T}$. Neurol India, 57(4): 406-410.

Leturcq F, Kaplan JC. 2000. Le diagnostic étiologique des dystrophies musculaires récessives. La Lettre du Neurologue, 4(5) : 250-258.

Liu J, Aoki M, Illa I, Wu C, Fardeau M, Angelini C, Serrano C, Urtizberea JA, Hentati F, Hamida MB, Bohlega S, Culper EJ, Amato AA, Bossie K, Oeltjen J, Bejaoui K, McKenna-Yasek D, Hosler BA, Schurr E, Arahata K, De Jong PJ, Brown RHJr. 1998. Dysferlin, a novel skeletal muscle gene, is mutated in Miyoshi myopathy and limb-girdle muscular dystrophy. Nat Genet, 20: 3136.

Mc Nally E, De Sa Moreira E, Duggan DJ, Bönnemann CG, Lisanti MP, Lidov HG, Vainzof M, Passos-Bueno MR, Hoffman EP, Zatz M, Kunkel LM. 1998. Caveolin 3 in muscular dystrophy. Hum. Molec. Genet., 7: 871-77. 
Merlini L, Kaplan JC, Navarro C, Barois A, Bonneau D, Brasa J, Echenne B, Gallano P, Jarre L, Jeanpierre M, Kalaydjieva L, Leturcq F, LeviGomes A, Toutain A, Tournev I, Urtizberea JA, Vallat JM, Voit T, Warter JM. 2000. Homogeneous phenotype of the gypsy lim-girdle muscular dystrophy with the gammasarcoglycan C283Y mutation. Neurol., 54: 1075-1079.

Moreira E, Vainzof M. Marie S, Nigro V, Zatz M, Passos-Bueno M. 1998. A first missense mutation in the deltasarcoglycan gene associated with a severe phenotype and frequency of limb-girdle muscular dystrophy type 2F (LGMD 2F) among brazilian sarcoglycanopathies. $J$. Med. Genet., 35: 951-963.

Nigro V, De Sa Moreira E, Piluso G, Vainzof M, Belsito A, Politano L, Puca AA, Passos-Bueno MR, Zatz M. 1996. Autosomal recessive limb-girdle muscular dystrophy, LGMD 2F, is caused by a mutation in the delta-sarcoglycan gene. Nature Genet., 14:195-198.

Sandona D, Betto R. 2009. Sarcoglycanopathies: molecular pathogenesis and therapeutic prospects. Expert Rev. Mol. Med., 28: 11-28.

Speer M, Vance JM, Grubber J, Graham FL, Stajich JM, Viles KD, Rogala A, Mc
Michael R, Chutkow J, Goldsmith C, Tim RW, and Pericak-Vance MA. 1999. Identification of a new dominant limbgirdle muscular dystrophy locus on chromosome 7. Am. J. Hum. Genet., 64: 556-562.

Urtasun M, Saenz A, Roudaut C, Poza JJ, Urtizberea JA, Cobo AM, Richard I, García Bragado F, Leturcq F, Kaplan JC, Martí Massó JF, Beckmann JS, López de Munain A. 1998. Limb-girdle muscular dystrophy in Guipuzcoa (Basque country, Spain). Brain, 121: 1735-1747.

Urtizberea JA. 2001. Myopathies de ceintures. Encycl. Med. Chir. Paris, 17-175-C-10; $9 \mathrm{p}$

Weiler T, Bashir T, Anderson LV, Davison K, Moss JA, Britton S, Nylen E, Keers S, Vafiadaki E, Greenberg CR, Bushby CR,Wrogemann K. 1999. Identical mutation in patients with limb-girdle muscular dystrophy type 2B or Miyoshi myopathy suggests a role for modifier gene(s). Hum. Molec. Genet., 8: 871-877. 